\title{
GALL BLADDER CANCER: A SINGLE CENTER EXPERIENCE
}

\author{
Rawal $S B^{1^{*}}$, Shah $K B^{2}$, Shrestha $D B^{3}$, Malla $S^{1}$, Rayamajhi $J^{1}, J h a M K^{2}$, Thapa $A^{2}$
}

\section{Affiliation}

1. Associate Professor, Department of Surgery, Nepalese Army Institute of Health Sciences, Nepal.

2. Assistant Professor, Department of Surgery, Nepalese Army Institute of Health Sciences, Nepal.

3. Medical Officer, Nepalese Army Institute of Health Sciences, Nepal.

\section{ARTICLE INFO}

Article History

$$
\begin{aligned}
& \text { Received : } 21 \text { April, } 2018 \\
& \text { Accepted : } 17 \text { August, } 2018 \\
& \text { Published : } 31 \text { August, } 2018
\end{aligned}
$$

(C) Authors retain copyright and grant the journal right of first publication with the work simultaneously licensed under Creative Commons Attribution License CC - BY 4.0 that allows others to share the work with an acknowledgment of the work's authorship and initial publication in this journal.

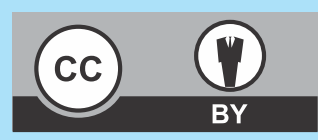

\section{ORA 69}

DOI: http://dx.doi.org/10.3126/bjhs.v3i2.20939

\section{* Corresponding Author}

Dr. Sushil Bahadur Rawal

Associate Professor

Department of Surgery

Nepalese Army Institute of Health Sciences ORCID: https://orcid.org/0000-0003-0070-369X

\section{Citation}

Rawal SB, Shah KB, Shrestha DB, Malla S, Rayamajhi J, Jha MK, Thapa A. Gall Bladder Cancer: A Single Center Experience. BJHS 2018;3(2)6:427-431.

\section{ABSTRACT \\ Introduction}

Gallbladder cancer (GBC) is the most common malignancy of the biliary tract, which is increasing in Southeast Asia. An early diagnosis is crucial for curative surgical resection. However, patients present late because at an early stage the initial symptoms are non- specific. Radical surgery is a challenging operation, and should be carried out only if RO resection is feasible.

\section{Objectives}

The aim of this study was to analyse the patient profile, clinical presentation and peri-operative outcome of patients who underwent various surgeries for GBC.

\section{Methodology}

Patients who had undergone surgery for GBC at our center over a 7 year period were identified from our database. A retrospective analysis from prospectively collected data was done. We analysed the outcome of these patients over the study period.

\section{Results}

Forty-four patients underwent surgery for GBC. There was a female preponderance (34 patients; $77 \%$ ) and the mean age of the patients was 54 years (range 22-76 years). Thirty-six patients (82\%) were diagnosed pre-operatively. Extended cholecystectomy (either segment IVb/V or $2 \mathrm{~cm}$ nonanatomical wedge resection of the liver) with standard lymph node clearance was performed in 35 patients (79\%). Peri-operative complications was seen in 11 patients (25\%) and in hospital mortality was seen in 2 patients $(4.5 \%)$

\section{Conclusion}

GBC is the most common malignancy of the biliary tract. As majority of patient present with locally advanced disease a potential curative resection warrants an aggressive surgical approach, which includes liver resection, lymph node clearance and resection of involved adjacent organs. Although this is a formidable surgery, it is the only chance for long-term survival.

\section{KEYWORDS}

Gall bladder cancer, Nepal, radical surgery 


\section{INTRODUCTION}

Gallbladder cancer (GBC) is the most common malignancy of the biliary tract and accounts for about $80 \%-95 \%$ of all cases. ${ }^{1}$ The incidence in Southeast Asia is on the rise and important risk factors recognized are age, female sex, congenital biliary tract anomalies and genetic predisposition. ${ }^{1}$ The disease occurs predominately in the elderly females and when it presents at an early stage the symptoms are indistinguishable from benign calculus disease. ${ }^{2}$ An early diagnosis is essential for curative surgical resection as it offers the best chance for long term survival. Studies have shown that for $\mathrm{T} 2$ and $\mathrm{T} 3$ disease radical resection has resulted in a significant survival advantage compared to simple cholecystectomy alone. ${ }^{3}$ In recent times, improved imaging modalities with radical surgical resection and adjuvant therapy have improved the outlook. ${ }^{1,4}$

This study aims to explore the patient profile, clinical presentation, different surgeries performed and the perioperative outcome of patients with GBC who underwent surgery at our center.

\section{METHODOLOGY}

Forty-four patients who had undergone surgical treatment for CAGB at Shree Birendra Hospital over a 7-year period between September 2010 to August 2017were identified from our database.

A retrospective analysis was done. Patients with inadequate data, patients with different histopathological diagnosis and patients who were either unresectable and/ orinoperable were excluded from the study. Patient related variables studied were age, sex, clinical presentation, type of surgery and the final pathological staging. All data was recorded in excel sheet and later entered and interpreted using SPSS version 22.

\section{RESULTS}

Out of the 43 patients operated with a pre-operative diagnosis of GBC,five patients were excluded because three patients had a histopathological diagnosis consistent with Hepatocellular carcinoma (HCC) and two patients had benign disease mimicking malignancy. There was a female preponderance in our study with a mean age of 54 . Twentynine patients presented with only right hypochondriac pain and seven patients with jaundice. Six patients with a pre-operative diagnosis of benign disease had incidental finding of GBC were also included in the study. Therefore, the total number of cases identified over this study period was 44. (Table 1.)
Table 1: Demographic and clinical profile of patients

Frequency (\%)

\section{Sex}

Males

$34(77 \%)$

Females

Age (Range)

54 (22-76) years

\section{Clinical Presentation}

Pain Abdomen

Jaundice

Pain and mass

Pain, jaundice and mass

Pain and jaundice

Abdominal mass

\section{Associated Cholelithiasis}

Stones present

Stones absent

\section{Time of Diagnosis}

Pre-operative

Intra-operative

Postoperative (Incidental)

Thirty-five patients (79\%) had associated cholelithiasis. Thirty-six patients (82\%) were diagnosed preoperatively by various imaging and/or tumor marker assessment while in two patients the diagnosis was confirmed intra-operatively with imprint cytology. Remaining six (12.2\%) were operated for cholelithiasis (4) and GB polyp (2).

Twenty-five patients underwent extended cholecystectomy and this was the most common performed radical surgery. (Table 2) Common Bile Duct (CBD) excision was performed in 17 patients based on the gross intra-operative finding of cystic duct or CBD involvement. Other radical surgeries were performed depending on the intra-operative findings on a case to case basis. (Table 2 ) The average lymph node yield per surgery was 8 .

Table: 2 Different surgeries performed for GBC

\begin{tabular}{lcc}
\multicolumn{1}{c}{ Surgery } & Frequency & Percent (\%) \\
Extended cholecystectomy & 25 & $56.8 \%$ \\
$\mathrm{C}+\mathrm{H}+\mathrm{N}$ & & \\
Wedge resection $\mathrm{C}+\mathrm{WR}+\mathrm{N}$ & 10 & $22.7 \%$ \\
More extensive $\mathrm{C}+\mathrm{H}+\mathrm{PD}+\mathrm{N}$ & 1 & $2 \%$ \\
More extensive C+WR+TC+N & 2 & $4.5 \%$ \\
Simple cholecystectomy & 2 & $4.5 \%$ \\
Segment III bypass & 1 & $2 \%$ \\
Open and close & 3 & $6.8 \%$
\end{tabular}

Note: $C=$ cholecystectomy, $H=$ segment $I V b \&$ V resection, $W R=$ wedge resection of liver, $P D=$ pancreaticoduodenectomy,

$T C=$ Transverse Colectomy, $N=$ Lymph node clearance 


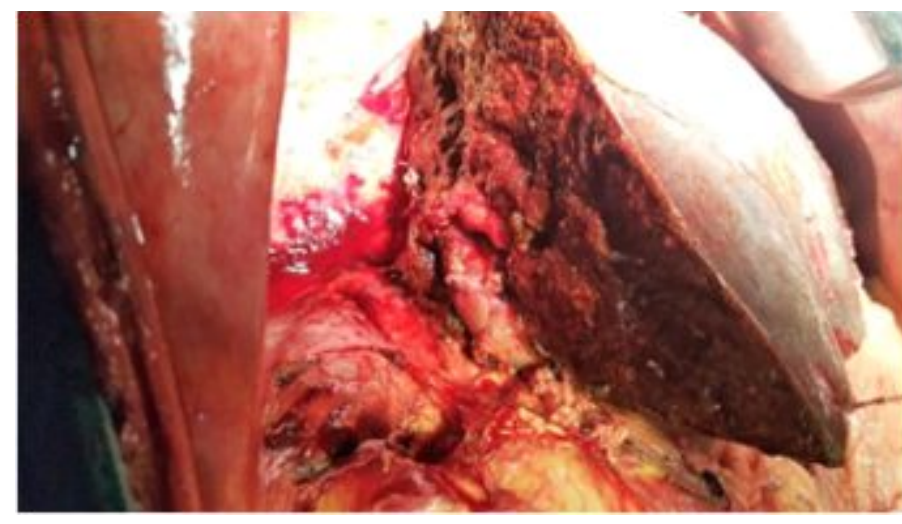

Figure 1. Photograph following right hepatectomy for carcinoma gall bladder with infiltration at the hepatic confluence preparing for hepaticojejunostomy.



Figure 3: Photograph following segment $4 b / 5$ excision and hepatoduodenal clearance for lymphadenectomy with CBD excision and hepaticojejunostomy.

The most common histological finding was that of adenocarcinoma in 40 patients followed by 3 cases of squamous cell carcinoma and 1 malignant fibrous histocytoma of Gallbladder wall. Most patients had disease with tumour ( $T$ ) involvement $\geq T 2$. (Table 3 ) and (Table 4)

Out of the 44 cases operated there was a total of 8 local and 3 systemic complications

\begin{tabular}{|c|c|c|c|}
\hline \multirow{2}{*}{$\begin{array}{l}\text { HPE of all the } \\
\text { operated cases of } \\
\text { CAGB }\end{array}$} & Adenocarcinoma & $\begin{array}{l}\text { Squamous cell } \\
\text { carcinoma }\end{array}$ & $\begin{array}{l}\text { Malignant Fibrous } \\
\text { Histocytoma }\end{array}$ \\
\hline & 40 & 3 & 1 \\
\hline \multicolumn{4}{|c|}{ Table 4: TNM staging of patients with Adenocarcinoma $(n=40)$} \\
\hline \multicolumn{2}{|c|}{$\begin{array}{l}\text { Tumor-Grade of patients } \\
\text { with Adenocarcinoma } \\
\text { ( } n=\text { patients }\end{array}$} & $\begin{array}{l}\text { odal Status } \\
\text { =patients) }\end{array}$ & Frequency \\
\hline \multicolumn{2}{|c|}{ pT1 (6) } & pNO (20) & Mo (39) \\
\hline \multicolumn{2}{|c|}{ pT2 (13) } & pN1 (14) & \\
\hline \multicolumn{2}{|c|}{ pT3 (11) } & pN2 (2) & $\mathrm{M} 1(1)$ \\
\hline pT4 (7) & Unk & known (4) & \\
\hline
\end{tabular}

Note: In 3 patients resection was not possible

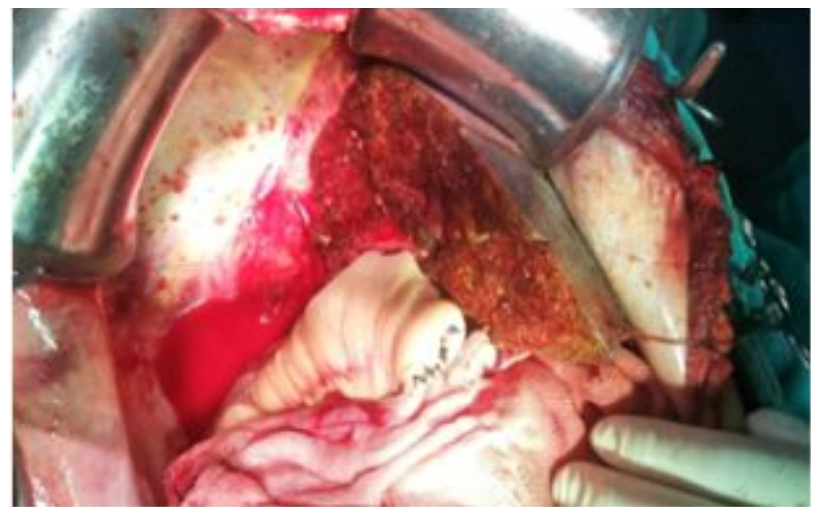

Figure 2: Completed left hepaticojejunostomy

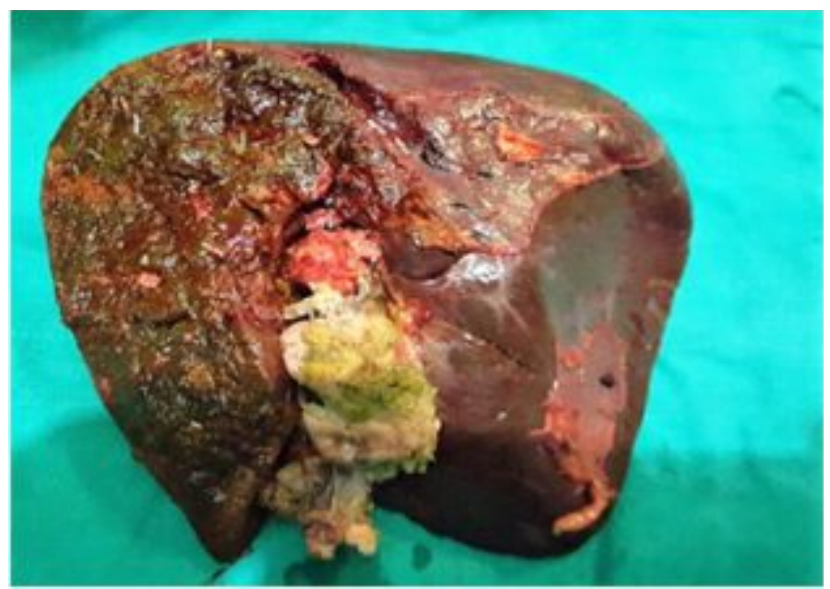

Figure 4: Specimen of right Hepatectomy with gall bladder carcinoma infiltrating into right hepatic duct

$\begin{array}{lc}\text { Table 5: Peri-operative morbidity and mortality } \\ \begin{array}{lc}\text { Complications } & \text { Number of } \\ \text { patients (\%) }\end{array} \\ \text { Morbidity } & \mathbf{1 1 ~ ( 2 5 \% ) ~} \\ \text { Local } & \mathbf{8} \\ \text { - Bile Leak } & 3 \\ \text { - Hemorrhaghe } & 2 \\ \text { - SSI } & 3 \\ \text { Systemic } & 3 \\ \text { - Pneumonia } & 2 \\ \text { - UTI } & 1 \\ \text { Mortality } & \mathbf{2 ~ ( 4 . 5 \% ) ~}\end{array}$

\section{DISCUSSION}

Our study shows a female preponderance with a mean age of 54 years. Majority of patients have presented with right hypochondriac pain followed by nausea and jaundice. These findings are consistent with other studies but the mean age of presentation was lower in our study. ${ }^{1}$

Another peculiar finding is the association with cholelithiasis which was found to be lower compared to other studies 
who have reported a higher association. ${ }^{5}$ However, GBC as an incidental findingin 4 patients with cholelithiasis and 2 patients with Gall Bladder polyp is higher as compared to other studies. ${ }^{6}$ This could be an implication of a high load of gallstone disease in our region.

Although a majority of patients had locally advanced disease we could attempt surgery with a curative intent in $90 \%$ of the cases. Patients with unresectable disease or distant metastasis on pre-operative contrast enhanced CT scan were excluded from the study. Current literature also advocates radical surgery in the form of liver resection for T2 tumors because majority of these cases they harbor residual liver disease. Studies have shown that cholecystectomy combined with liver resection (either $2 \mathrm{~cm}$ wedge or segment IVb \& V) improves the outcome over cholecystectomy alone. ${ }^{7,8}$ In the absence of metastatic disease wherever possible an $\mathrm{R} 0$ resection should be contemplated. ${ }^{9-11}$ Three of our patients had locally advanced disease and had undergone extensive surgeries which included pancreaticoduodenectomy and transverse colectomy. Such aggressive surgery for bulky disease has shown to prolong survival and improve quality of life ${ }^{12}$, but this can be justified only if $\mathrm{R} 0$ resection can be achieved and in a patient with a good performance status. ${ }^{13}$ However, in such cases only partial or sleeve resection of the involved organ is advisable. ${ }^{14}$ Our policy of avoiding routine excision of the extra hepatic bile duct to facilitate lymph node clearance is consistent with other studies. ${ }^{15,16}$ In the majority of the cases standard regional lymphadenectomy was carried out and as stated earlier the average lymph node yield was 8.

Most gall bladder cancer are of the adenocarcinoma variant and this finding is also seen in this study. ${ }^{11,17}$

In spite of a $25 \%$ perioperative morbidity which include both local and systemic complications the in hospital mortality of this study $(4.5 \%)$ is comparatively lower than other centers. ${ }^{12}$ This may be because of including patients with incidental GBC where the surgical outcome is markedly better. The limitations of this study is that it fails to highlight the follow up and the long term survival of these patients.

\section{REFERENCES}

1. Hundal R, Shaffer EA. Gallbladder cancer: epidemiology and outcome. Clin Epidemiol. 2014;6(6):99-109. PMid:24634588 PMCid:PMC3952897

2. Piehler JM, Crichlow RW. Primary carcinoma of the gallbladder. Surg Obstet Gynecol. 1978;147(6):929-42. PMID:362580

3. Foster JM, Hoshi H, Gibbs JF, Iyer R, Javle M, Chu Q, et al. Gallbladder cancer: defining the indications for primary radical resection and radical re-resection. Ann Surg Oncol. 2007;14(2):833-40. https://doi.org/10.1245/s10434-006-9097-6 PMid:17103074

4. Cleary SP, Dawson LA, Knox JJ, Gallinger S. Cancer of the gallbladder and extrahepatic bile ducts. Curr Probl Surg. 2007;44(7):396-482. https://doi.org/10.1067/j.cpsurg.2007.04.006 PMid:17693325

\section{CONCLUSION}

Cancer of the Gall Bladder is the most common biliary tract tumor in our region and can even appear in a younger age group. Early diagnosis, proper imaging to stage the lesion followed by aggressive surgical resection is the best treatment modality. With refinements in the surgical techniques, locally advanced cases can undergo radical surgery with an acceptable morbidity and mortality. However, because of the formidable nature of the operation, resection for advanced carcinoma gallbladder is recommended only if a curative $\mathrm{RO}$ resection is possible.

\section{RECOMMENDATIONS}

Treatment of gall bladder cancer is primarily surgical, only advance cases subjected to palliative chemotherapy with no significant evidence of improved prognosis: Symptomatic gall bladder cancer have an overall poor prognosis as compared to the ones diagnosed incidentally. Coexisting jaundice in these cases is not a contraindication for surgery but needs comprehensive work up.

\section{LIMITATION OF THIS STUDY}

The absolute number of patients in this study is relatively low to bring about a comparative result. No comparison has been made between patients who have undergone surgery to the ones managed conservatively. Disease free survival and overall survival has not been tabulated statistically.

\section{ACKNOWLEDGEMENTS}

We extend our sincere gratitude to the team of intensivists and interventional radiologists who have put in all efforts in the management of these complicated patients.

\section{CONFLICT OF INTEREST}

None declared

\section{FINANCIAL DISCLOSURE}

None
5. Gueleyik G, Gueleyik E, Oztuerk A, Unalmiser S. Gallbladder carcinoma associated with gallstones. Acta Chir Belg. 2002;102(3):203-6. https://doi.org/10.1080/00015458.2002.11679296

6. Tantia O, Jain M, Khanna S, Sen B. Incidental carcinoma gallbladder during laparoscopic cholecystectomy for symptomatic gall stone disease. Surg Endosc. 2009;23(9):2041-6.https://doi.org/ 10.1007/ s00464-008-9950-8 PMid:18443860

7. Jayaraman S, Jarnagin WR. Management of gallbladder cancer. Gastroenterol Clin N Am. 2010;39(2):331-42. https://doi.org/10. 1016/j.gtc.2010.02.006 PMid:20478489

8. Bartlett DL, Fong Y, Fortner JG, Brennan MF, Blumgart LH. Long-term results after resection for gallbladder cancer. Implications for staging and management. Ann Surg. 1996;224(5):639. https://doi.org/ 10.1097/00000658-199611000-00008 PMid:8916879 PMCid: PMC1235441 
9. Nishio H, Ebata T, Yokoyama $Y$, Igami T, Sugawara G, Nagino M. Gallbladder cancer involving the extrahepatic bile duct is worthy of resection. Ann Surg. 2011;253(5):953-60. https://doi.org/ 10.1097/SLA.0b013e318216f5f3 PMid:21490453

10. Miyazaki M, Itoh H, Ambiru S, Shimizu H, Togawa A, Gohchi E, et al. Radical surgery for advanced gallbladder carcinoma. $\mathrm{Br} J$ Surg. 1996 1;83(4):478-81. https://doi.org/10.1002/bjs.1800830413 PMid: 8665234

11. Dwivedi AN, Jain S, Dixit R. Gall bladder carcinoma: Aggressive malignancy with protean loco-regional and distant spread. World J Clin Cases. 2015;3(3):231-44. https://doi.org/10.12998/ wjcc.v3.i3. 231 PMid:25789296 PMCid:PMC4360495

12. Kondo S, Nimura Y, Hayakawa N, Kamiya J, Nagino M, Uesaka K. Extensive surgery for carcinoma of the gall bladder. Br J Surg. 2002; 89(2):179-84. https://doi.org/10.1046/j.0007-1323.2001.02001. xhttps://doi.org/10.1046/j.1365-2168.2002.02001.xPMid:11856130
13. Sasaki R, Takahashi M, Funato O, Nitta H, Murakami M, Kawamura H, et al. Hepatopancreaticoduodenectomy with wide lymph node dissection for locally advanced carcinoma of the gallbladder-long term results. Hepatogastroenterology. 2002;49(46):912-5. PMid:12143239

14. Agarwal AK, Mandal S, Singh S, Sakhuja P, Puri S. Gallbladder cancer with duodenal infiltration: is it still resectable? J Gastrointest Surg. 2007;11(12):1722-7. https://doi.org/10.1007/s11605-007-0320-y PMid:17906907

15. Shih SP, Schulick RD, Cameron JL, Lillemoe KD, Pitt HA, Choti MA, et al. Gall Bladder cancer: the role of laparoscopy and radical resection. Ann Surg. 2007;245(6):893-901. https://doi.org/10.1097/ SLA. Ob013e31806beec2 PMid:17522515 PMCid:PMC1876959

16. Kokudo N, Makuuchi M, Natori T, Sakamoto Y, Yamamoto J, Seki M, et al. Strategies for surgical treatment of gallbladder cancer bason on information available before resection. Arch Surg. 2003;138(7):741- 